\title{
Teacher's Perception on How Multisensory Approach in Teaching Reading for EYL with Dyslexia
}

\author{
Nina Puspitaloka ${ }^{1, *}$ Hermawati Syarif ${ }^{2}$ Ermanto $^{2}$ \\ ${ }^{1}$ Universitas Singaperbangsa Karawang, Karawang 41361, Indonesia \\ ${ }^{2}$ Universitas Negeri Padang, Padang 25171, Indonesia \\ *Corresponding author. Email: nina.puspitaloka@fkip.unsika.ac.id
}

\begin{abstract}
This study aimed to implementing a multisensory approach in teaching reading for dyslexic EYL and determine the teacher's perception on learning to read English using a multisensory approach towards EYL with dyslexia. Participants in this study were English teachers at one of inclusive elementary school in Karawang. This research design used a qualitative approach and descriptive methods. In data collection, researchers used interviews while data analysis was adapted from Braun and Clarke (2013). The results of this study indicated that a multisensory approach is an appropriate approach to be applied in learning to read English for students with dyslexia. Teachers can use learning media as support for multisensory use so that in the learning process students can use more than one sense. The use of this approach has a positive effect on learning to read English for students with dyslexia, but this approach requires a variety of supporting media which is quite expensive. The multisensory approach also cannot be used with short learning times because students need a long time to learn.
\end{abstract}

Keywords: Multisensory, Teaching Reading, Dyslexia

\section{INTRODUCTION}

Much research is conducted based on the problems that exist in learning. These problems can be in the form of learning difficulties experienced by students, one of which is a lack of students, dyslexia. Dyslexia is a learning difficulty that is common among students [1]. Even though they have difficulty in reading, dyslexic students may have good IQs and other abilities [2]. Dyslexia is a special learning difficulty group in which a dyslexic child has difficulty reading, spelling, writing, speaking, and listening. When a dyslexic child reads a word, the pronunciation of the syllable is often reversed, for example, "was" becomes "saw" and "now" becomes "won" and others.

In general, people with dyslexia are difficult to detect by the public. Currently in Indonesia, we still use a general view to assess children who have difficulty reading, and dyslexic children are still considered naughty, lazy, and must be punished [2]. Teachers also lack understanding of dyslexic students. They do not have the readiness to treat dyslexic students appropriately at school because they have never received special training on dyslexia. Parents and teachers need an understanding of the characteristics of dyslexic children so that they get the right treatment and can self-actualize. Children with dyslexia need proper treatment and explore another potential in themselves and before treatment, teachers and parents must know about dyslexia first [3]. After knowing the characteristics of children with dyslexia, parents, teachers, or education practitioners must determine the appropriate learning method to improve the child's reading and writing skills [2].

Teaching reading by the teacher is quite a complex activity. What's more, teaching English reading to students with dyslexia is becoming more difficult for English teachers. Therefore, the use of the right learning approach is needed in this case. An approach that can support and assist students with dyslexia in learning to read. The use of methods where students use more than one sense can help in learning to read. According to Mencer \& Mencer in [4] using more than one sense or known as VAKT (visual, audio, kinesthetic, and tactile can improve students' learning ability in obtaining information. Multisensory is one approach that can be used to support students' reading learning. with dyslexia. Activities that combine sensory activity and use four modalities such as seeing, hearing, and touching are included in a multisensory approach [4]. Goswami [5] and Roulstone et al. [6] state that multisensory pedagogy is usually the most effective method. for students with difficulties in learning to read.

Several studies have revealed how multisensory approach assist students in learning reading skills. Kamala [7] where teaching reading skills through a multisensory approach is made easier for students with dyslexia. Obaid's research [8] also explains the significant differences through post-test. Smith [9] found that multisensory can be used when helping dyslexic students to improve their reading skills in English classrooms. Ho, Lam and $\mathrm{Au} \mathrm{[10]} \mathrm{applied} \mathrm{multisensory} \mathrm{training} \mathrm{more}$ 
effectively than traditional learning to read and write Chines.

Previous research has revealed the application of multisensory approach to students. However, no one has examined the use of multisensory for students in terms of teacher perceptions. Therefore, this study aims to implementing a multisensory approach to teach reading for dyslexic EYL and determine the perceptions of teachers in applying a multisensory approach to teach reading for EYL with dyslexia.

\section{METHOD}

This study used a qualitative approach and descriptive methods. The site in this research was one of an inclusive elementary school in Karawang. This school is one of school which held inclusive education in around Karawang area. This inclusive school has normal students and students who have learning difficulties such as dyslexia that placed in one class. The participant in this research is a teacher (special teacher for students diagnosed with special needs).

To collect the data, the researcher conducted interviews with the English teacher. The interviewer aimed to obtain in-depth information about the topic of teaching and learning activities, especially for students with dyslexia. This was used to determine teacher perceptions after using multisensory approach for students with dyslexia. The semi-structured interview was used by researchers to obtain data where conversations are held between researchers and participants. In-depth interviews were utilized extensively as an interviewing format possibly with an individual or sometimes even with a group [11]. The researcher analyzed the data by adapting from Braun and Clarke [12]. According to them, there are six steps in conducting data analysis, namely familiarization with data, generation of initial codes, reviewing themes, defining and naming themes, producing the report.

\section{RESULT AND DISCUSSION 3.1. Result}

The results of this study described the teacher's perceptions of the application of a multisensory approach to EYL with dyslexia in reading learning and describe the application of a multisensory approach in learning to read students with dyslexia. The results of the study were obtained from interviews conducted with English teachers who taught students with dyslexia.

3.1.1. Teacher's perceptions of multisensory approach in teaching reading to dyslexic students

In this teacher's perception, the teacher explained three things related to the application of a multisensory approach in teaching reading students with dyslexia, namely teaching creativity is necessary, supporting media, advantages, and disadvantages.

\subsubsection{Teaching creativity is necessary}

Creativity in learning is very important in teaching English to young learners. The teacher revealed that the use of sensory methods is not always appropriate in all lessons. The teacher must also understand the conditions of each student (constraints, abilities, and needs of students), subjects to be studied, learning materials, and learning objectives. Learning that only uses one method makes students easily bored so that the creativity of the teacher in implementing learning activities is needed so that students become active learners. To foster creativity in the learning process and reduce student boredom, the teacher used several media, such as English songs (motion-rhythm), flashcards, storytelling (using pictures as puppets), guessing words, etc.

\subsubsection{Supporting media}

The use of media was used by teachers to support the application of a multisensory approach. The teacher said that everything can be used as a learning medium if it is lined with the learning objectives. When the teacher taught at school, the teacher is facilitated by having various supporting media such as once tools, lego, small balls, puzzles, Montessori media, etc. The teacher also said that all this time Lego, puzzles, and Montessori tools were media that could improve the mood of students with dyslexia in learning to read. The teacher put the text of the story under some supporting media then the teacher asked students to choose what media they played, so students must read the text well while playing.

\subsubsection{Advantages and disadvantages}

The multisensory approach had advantages in the teaching and learning process such as achieving learning objectives, child-centered, child-friendly, motivated children to learn, made students more confident, and optimized children's growth. The teacher stated that the multisensory approach can achieve student learning goals because it is a student-friendly approach that makes students feel happy while studying. Besides, multisensory is a varied approach which means it can meet the needs of dyslexic students. Through the use of this approach, the teacher can also motivate students to learn and made students more confident and optimize student understanding of lessons.

The teacher stated that there are disadvantages in using the multisensory approach. The media required for this approach is quite expensive, making it difficult to get approval from the school to propose to purchase media because the price of the media continues to be adjusted to the school budget. The use of a multisensory approach also required a long time in the learning process because students carry out learning activities using more than one sense. This shows that a multisensory approach will not be suitable if it is applied to learning with only 1 hour.

3.1.2. The implementation of multisensory approach in teaching reading to students' with dyslexia

There are six points that the teacher takes when applying a multi-cognitive approach to teaching dyslexic students. 
The six points consist of the learning adjustment, used code-switching, used concrete, semi-concrete, and abstract media, learning agreement, student's reward, and teacher and parent's communications.

\subsubsection{Learning adjustment}

The teacher must know the student's condition before starting learning. This affects the adjustment of learning to learn objectives. Learning objectives can be narrowed down to make it easier for the rest of the student's condition does not allow or does not master the material from the initial learning objectives. This is a learning adjustment that the teacher undertakes to support student understanding

\subsubsection{Code-switching}

The teacher said that using code-switching the learning materials can be more comprehensible for the students. The teacher started the lesson by reading a piece of the text in the textbook about "The things that are in the classroom". In delivering the material the teacher used code-switching which means the teacher uses the students' first language and then it changed into English. Then, the teacher asked the students to mention what items are available in the classroom with their language. After the students answered and mentioned names of things that are in the classroom in their first language, the teacher helped the students to translate into English while the teacher held the objects that were already mentioned by the students

\subsubsection{Using concrete, semi-concrete, abstract media}

The teacher uses abstract, semi-concrete, and concrete media to support a multisensory approach in learning to read English for students with dyslexia. Teachers believed that it can stimulate students' senses (visual, audio, kinesthetic). Media can also be replaced with flashcards. After students answered and mentioned the names of objects in the classroom in their mother tongue, the teacher helped students translate into English while the teacher held the objects that have been mentioned by the students.

\subsubsection{Learning agreement}

The teacher conveyed that at some point students with dyslexia experience 'tantrums' or mood swings that occured unexpectedly because many dyslexic students cannot express their feelings directly. Responding to this condition, the teacher made an agreement with the students at the beginning of the lesson. Example: the teacher can make an agreement "if you can read/write the text correctly, the students can draw for two minutes". (Note: students' drawings are still in the context of the learning material. Students can draw hats / books / bags / pencils / pens).

\subsubsection{Rewards}

Dyslexic students experienced "tantrums". Therefore teachers must motivated students. When students go through the stages (copying, spelling, reading, and writing words), students can get rewards. Teachers often gave simple gifts such as saying "you are cool!", Tos, and giving star stickers, etc to increase student motivation and create a good atmosphere.

3.1.2.6. The teachers and parent's communication

After learning is complete, the teacher usually made notes in student journals. The journal was used as a reference in evaluating with parents regarding the progress of the student learning process or the success of each student in each meeting.

\subsection{Discussion}

Dyslexic students have different characteristics from normal students. Dyslexic students sometimes show tantrums or mood swings. This causes them to get bored quickly in the learning process. Therefore, the use of monotonous learning methods cannot be used continuously for students with dyslexia. Besides, the use of a multisensory approach is effective in reading learning for students with dyslexia.

In applying a multisensory approach, the teacher used concrete, semi-concrete, abstract media to stimulate the students' senses. This aimed to develop students' understanding of the types of objects around them using English. In line with Praveen, et.al. [13] that teachers used students' senses to understand information and connect with ideas they already know, take advantage of nonverbal reasoning skills, understand relationships between concepts, and store information.

The teacher adjusts between the methods and subjects, objectives, materials, and conditions of the child. As Chinn [14] points out, adjustments made to help students with dyslexia will help other students as well. Teachers are also encouraged to create a pleasant learning atmosphere during the learning process. To make this happen, it requires the creativity of teachers in using various teaching methods, but still adapting to the needs and conditions of students. Sudek, et al [15] stated that dyslexia-friendly classrooms must have a variety of authentic listening and reading materials that can motivate and provide communicative goals. Furthermore, these findings are in line with Kamala [7] that students with dyslexia can be taught to read effectively but they need different strategies to develop their reading skills, through a multisensory approach making dyslexic students learn reading skills easily.

To facilitate student understanding as well as students' listening and speaking skills in English, teachers use code-switching during the teaching-learning process for dyslexic students. The reason why teachers use codeswitching is that it can facilitate students to learn. English is effective and efficient (Fathimah [16]; Puspawati, [17]).

The use of instructional media is also expected to increase students 'understanding of reading learning, the learning media can increase students' reading interest which will be conveyed by the teacher. Learning media is also considered to be able to reduce student saturation and concentration. This can make the classroom atmosphere more interesting and also persuade students 
to learn English without forcing them. The teacher asks students to "copy, spell, read and write" in reading learning using a multisensory approach for students with dyslexia. In another study, Holešinská [18] also used a multisensory type of approach in his study by exploring several activities to help dyslexics with their spelling. One activity called "Track, Copy, and Remember" uses a chart with a few spelling words.

Giving rewards makes students focus on the learning process (Irawati \& Syafei, [19]). The results showed that the teacher gave awards to students who had shown good behavior during the learning process. Rewards are also used by the teacher to increase student motivation. The use of a multisensory approach takes a long time, but it will make students active and encourage student motivation. Praptiningrum [20] said that a multisensory approach can help students be active and interactive if accompanied by motivation and encouragement from the teacher.

\section{CONCLUSION}

A multisensory approach can help students with dyslexia to read English, but it is not always appropriate to be used in every learning process for students with dyslexia. Students with dyslexia experience mood swings or "tantrums". Therefore, teaching and learning activities must be supported by creative and varied methods and adapted to the subjects, objectives, materials, and conditions of each student. The advantages of this approach are the achievement of learning objectives, being child-centered, child-friendly, motivating children in learning, making students more confident, and optimizing children's development. The disadvantages are the high cost of providing supporting media and the limited time allocation for implementation. To apply multisensory approach in learning to read EYL with dyslexia, the teacher uses code-switching and uses various media to convey material. To prevent boredom from unexpected tantrums of students, the teacher makes deals with students. Teachers often provide rewards as positive reinforcement if students pass the learning process or show good attitudes. The teacher also pays attention to following up on student learning success

This study suggests teachers who teach reading English by using multisensory approach in carrying out teaching and learning activities to see the conditions of each student and need to be adjusted to the learning material. Teachers must be able to carry out varied and modified learning so that students do not get bored easily. For other researchers who want to do similar topics and samples, this research can be a reference before the research is carried out. However, this multisensory approach is not only used to teach reading words in English but can also be used to teach reading in Indonesian.

\section{REFERENCES}

[1] Kerig, P. K., \& Wenar, C. (2006). Psychopathologies of the Adolescent Transition: Eating Disorders and Substance Abuse. I: Developmental Psychopathology. From Infancy through Adolescence. New York: McGraw-Hill, 359-403.

[2] Prasetya, Z. T. (2017). Metode fernald untuk meningkatkan kemampuan membaca pada anak disleksia (Doctoral dissertation, University of Muhammadiyah Malang).

[3] Aphroditta, M. (2012). Panduan lengkap Orang tua dan Guru untuk Anak dengan Disleksia. Jogjakarta: Javalitera.

[4] Murphy, N. (1997). A Multisensory vs Conventional Approach to Teaching Spelling.

[5] Goswami, U. (2015). Children's Cognitive Development and Learning CPRT Research Survey 3 (new series) Cambridge Primary Review Trust.

[6] Roulstone, S., Wren, Y., Bakopoulou, I., \& Lindsay, G. (2012). Interventions for children with speech, language and communication needs: An exploration of current practice. Child Language Teaching and Therapy, 28(3), 325-341.

[7] Kamala, R. (2014). Multisensory approach to reading skills of dyslexic students. IOSR Journal of Humanities and Social Science, 19(5), 32-34.

[8] Obaid, M. A. S. (2013). The impact of using multisensory approach for teaching students with learning disabilities. Journal of International Education Research (JIER), 9(1), 75-82.

[9] Smith, A. (2013). U.S. Patent Application No. $13 / 848,190$.

[10] Ho, C. S. H., Lam, E. Y. C., \& Au, A. (2001). The effectiveness of multisensory training in improving reading and writing skills of Chinese dyslexic children. Psychologia, 44(4), 269-280.

[11] Corbin, J., \& Strauss, A. (2014). Basics of qualitative research: Techniques and procedures for developing grounded theory. Sage publications.

[12] Braun, V., \& Clarke, V. (2013). Successful qualitative research: A practical guide for beginners. sage.

[13] Praveen, V. K., Vedhanarayanan, B., Mal, A., Mishra, R. K., \& Ajayaghosh, A. (2020). Self- 
Assembled Extended $\pi$-Systems for Sensing and Security Applications. Accounts of Chemical Research, 53(2), 496-507.

[14] Chinn, S. (2001). Learning styles and mathematics. Dyslexia: Successful Inclusion in the Secondary School, 117.

[15] Sudek, E., \& Encinas, F. Strategies for Elementary Dyslexic Students' English Language Learning: Crowdsourcing and Reviewing Research Literature.

[16] Fathimah, D. N. (2016). Why is there CodeSwitching in EFL Classroom?: A Case Study in a Vocational School in Cimahi West-Java. Jurnal Pendidikan Bahasa dan Sastra, 16(1), 70-77.

[17] Puspawati, I. (2018). Teachers' Use of Code Switching in EFL Classroom and its Functions. Journal of Foreign Language Teaching and Learning, 3(1), 4251.

[18] Holešinská, A. (2006). Teaching English as a foreign language to students with learning difficulties (Doctoral dissertation, Masarykova univerzita, Pedagogická fakulta).

[19] Irawati, I., \& Syafei, A. F. R. (2016). The use of reward and punishment to increase young learners'motivation in learning english as foreign language adapted to indonesian context. Journal of English Language Teaching, 5(1), 265-271.

[20] Nurdayati Praptiningrum, P. (2009). Metode Multisensori untuk Mengembangkan Kemampuan Membaca Anak Disleksia di SD Inklusi. Jurnal Penelitian Ilmu Pendidikan, 2(2). 